\title{
DISTRIBUTION OF JERUSALEM ARTICHOKE (Helianthus tuberosus L.) N THE CANTON SARAJEVO AREA
}

Nijaz SULJIĆ ${ }^{1}$, Drena GADŽO² ${ }^{2}$ Nedžad KARIĆ2 Mirha ĐIKIĆ $^{2 *}$

UDK $631.4: 633.88(497.6)$

\begin{abstract}
Invasive plant species which also include Jerusalem artichoke (Helianthus tuberosus L.), are plants which come from other floral-geographical areas and in process of competition they suppress autochthonous gene by conquering available ecological systems. The spread of foreign species is becoming serious threat to the conservation of natural and semi-natural biotopes. Jerusalem artichoke belongs to the family Asteraceae and it originates from America. İt is perennial plant with highly developed root in form of irregular tubers from which emerges each year more perennial stalks. İt grows up to $3 \mathrm{~m}$ height. İn our conditions it does not produce seed, it is reproducing vegetative by tubers. İt is used for production of alcohol, in the pharmaceutical and food industry, as fodder and medicinal plant for more than 100 years. In the second half of $20^{\text {th }}$ century it has become serious invasive species in all parts of Europe. On the EPPO list Jerusalem artichoke belongs to 34 dangerous invasive species. It is considered as weed of natural areas but it can occur on the agricultural soils and ruderal lands. The aim of this paper is to examine the prevalence of Jerusalem artichoke in the area of Sarajevo Canton. The obtained data can be used for its adequate and more successful suppression.
\end{abstract}

Keywords: invasive species, Jerusalem artichoke, Sarajevo

\section{INTRODUCTION}

Jerusalem artichoke belongs to the family Asteraceae. It is used for the alcohol production, forage crop, in the pharmaceutical and food industry (Seiler, 2007), as well as a medicament in the home medicine. Healing properties of this species are scientifically proven (Šilić and Abadžić, 2000). It originally comes from North America where American Indians were using it as a food and medicament and from the $16^{\text {th }}$ century it is grown in many countries

\footnotetext{
${ }^{1}$ Nijaz Suljić, Agro plus doo, Sarajevo

${ }^{2}$ Faculty of Agricultural and Food Sciences, University of Sarajevo, Zmaja od Bosne 8, 71000 Sarajevo, Bosnia and Hercegovina

*Corresponding author: m.djikic@ppf.unsa.ba
} 
of Central Europe (Šilić and Abadžić, 2000). Today, it is cultivated and escaping, often invasive, in many temperate areas in Europe, Asia, New Zealand, and tropical South America (Weber, 2003). Despite the aforementioned benefits Jerusalem artichoke is considered as weed in the natural areas, but it can also occur on the arable land and ruderal areas. Labant-Hoffmann and Kazinczi (2014) said that in the second half of $20^{\text {th }}$ century it became serious invasive species in every part of Europe. On the EPPO (European Plant Protection Organization) it is placed on the $34^{\text {th }}$ place of dangerous invasive species.

Jerusalem artichoke is perennial plant with well-developed root in the form of irregular tubers. It grows up to $3 \mathrm{~m}$ height. It has strong, upright, one-year stalk. Raw tuber has a taste of hazelnuts and cooked one has a taste of artichoke. It grows in warm and continental climate. Often it is found near rivers and brooks and sometimes as a decoration in gardens. It is perennial plant and in our region it multiplies by tubers. Tubers are spindle-shaped and elongated and in contrast of potato they contain inulin instead of starch. Often it is found on fertile and moist soil, but it can also grow on the poor soil such as near the roads, on the edges of the forest, on the forest clearings, near the embankments and on the abandoned soils. It grows all the time because it is selfregenerated so we can say that it is indestructible. In Bosnia and Herzegovina it appears on the large number of regions in Central Bosnia (by the river Bosna) and in Herzegovina (by the river Neretva). It is also found by the river Spreča, but it already spread on abandoned ruderal habitats and also on crops. It was found in corn, sunflower, small grains and alfalfa (Bećar et al., 2009). Radovanović et al. (2013) for Helianthus tuberosus $L$. said that it grows on the wide territory of Serbia and Romania.

This plant species has a unique chemical composition and as the most precious ingredient stands out inulin. Inulin has a favorable impact on a human health and includes reduced risk for cardiovascular diseases, probiotic effect, prevention and/or reduction of osteoporosis. Terzić et al. (2007) consider Jerusalem artichoke as a food source. It is recognized as a potential source of resistance on some diseases that occur in sunflowers (Terzić et al., 2011).

Jerusalem artichoke is considered as a dangerous weed on agricultural and nonagricultural soils, so its repression has been a topic for a large number of researchers. Geophytes are the weeds that are hard to control and this species is one of them. Mowing it two times per year can significantly reduce it. Other researchers suggest that it should be mowed many times per year, every time when the plants height reaches $50 \mathrm{~cm}$. Chemical repression is the best just before blooming and the efficiency is than $100 \%$. The biggest problem for chemical control is that this species is mainly found in natural regions where this type of control is not allowed. The complete destruction of tillers and significant reduction of underground parts of the plant happened when the chemical and mechanical repression was made. According to the mentioned, best type of control is 
combination of chemical and mechanical treatments (Labant-Hoffmann and Kazinczi, 2014). Schittenhelm (1996) examined Jerusalem artichoke as a crop. After removing the tubers, significant number of them remains in soil. These tubers can make serious problems as a weed in the next crop. In the corn it can reduce yield by $91 \%$ and in the sugar beet by $81 \%$. Control of Jerusalem artichoke is also possible by burning. Chemical and burning control is not recommended in the urban areas and near rivers.

There are no detailed data on distribution of Jerusalem artichoke in the Sarajevo Canton, so it was impossible to follow the dynamics of its spread and development over past years. The aim of this paper is to map populations of Jerusalem artichoke in area of Sarajevo Canton in order to ensure its monitoring and control in the future.

\section{MATERIAL AND METHODS}

The area of studying this invasive species is Canton Sarajevo. Canton Sarajevo is located in central part of Bosnia and Herzegovina based in city of Sarajevo. The area of the Canton Sarajevo is $1,276.9 \mathrm{~km}^{2}$. Canton Sarajevo is under the influence of middleeurope continental climate from the north and mediterian climate from the south. Intertwining of these impacts and diversity of relief give this area feature of moderately continental climate. Average annual temperature is $9.5^{\circ} \mathrm{C}$. Average annual precipitation is 1,000 to $1,200 \mathrm{~mm}$. Snow can be heavy in this area, especially on higher altitudes.

Presence and distribution of invasive weed species was recorded by square method $(0.25$ $\mathrm{m}^{2}$ ) (Novak et al., 2009).This method implies on the identification of species, number of stalks, height of plant, and phase of growing and development. Research was conducted in the period from April to October because it is the period of active vegetation. Ruderal areas, meadows and agricultural areas were examined.

All Jerusalem artichoke stands were photographed, mapped and assigned size classes $\left(0-10\right.$ plants per $\mathrm{m}^{2}, 10-50$ plant per $\mathrm{m}^{2}$ and $\left.>50 \mathrm{~m}^{2}\right)$.

\section{RESULTS AND DISCUSSION}

In this research 42 habitats of Jerusalem artichoke were found. The highest number of locations was found in the west part of Canton Sarajevo, municipality Ilidža. Municipalities Hadžići, Novi Grad and Vogošća comes after Ilidža, while in other municipalities only 1 or 2 locations were found (Table 1). 
Table 1. Number and size of locations of Jerusalem artichoke in Canton Sarajevo by municipalities

\begin{tabular}{lcccc}
\hline Municipality & & Number of plants per $\mathbf{~ m}^{\mathbf{2}}$ & \multirow{2}{*}{ TOTAL } \\
\hline \hline Ilijaš & $\mathbf{0 - 1 0}$ & $\mathbf{1 0 - 5 0}$ & $\mathbf{5 0}$ & \\
\hline Ilidža & 0 & 1 & 0 & 1 \\
\hline Hadžići & 3 & 11 & 6 & 20 \\
\hline Trnovo & 0 & 7 & 0 & 7 \\
\hline Novi Grad & 0 & 0 & 1 & 1 \\
\hline Stari Grad & 0 & 4 & 0 & 4 \\
\hline Novo Sarajevo & 0 & 2 & 0 & 2 \\
Centar & 1 & 0 & 0 & 1 \\
\hline Vogošća & 1 & 0 & 1 & 2 \\
\hline TOTAL & 0 & 4 & 0 & 4 \\
\hline & $\mathbf{5}$ & $\mathbf{2 9}$ & $\mathbf{8}$ & $\mathbf{4 2}$ \\
\hline
\end{tabular}

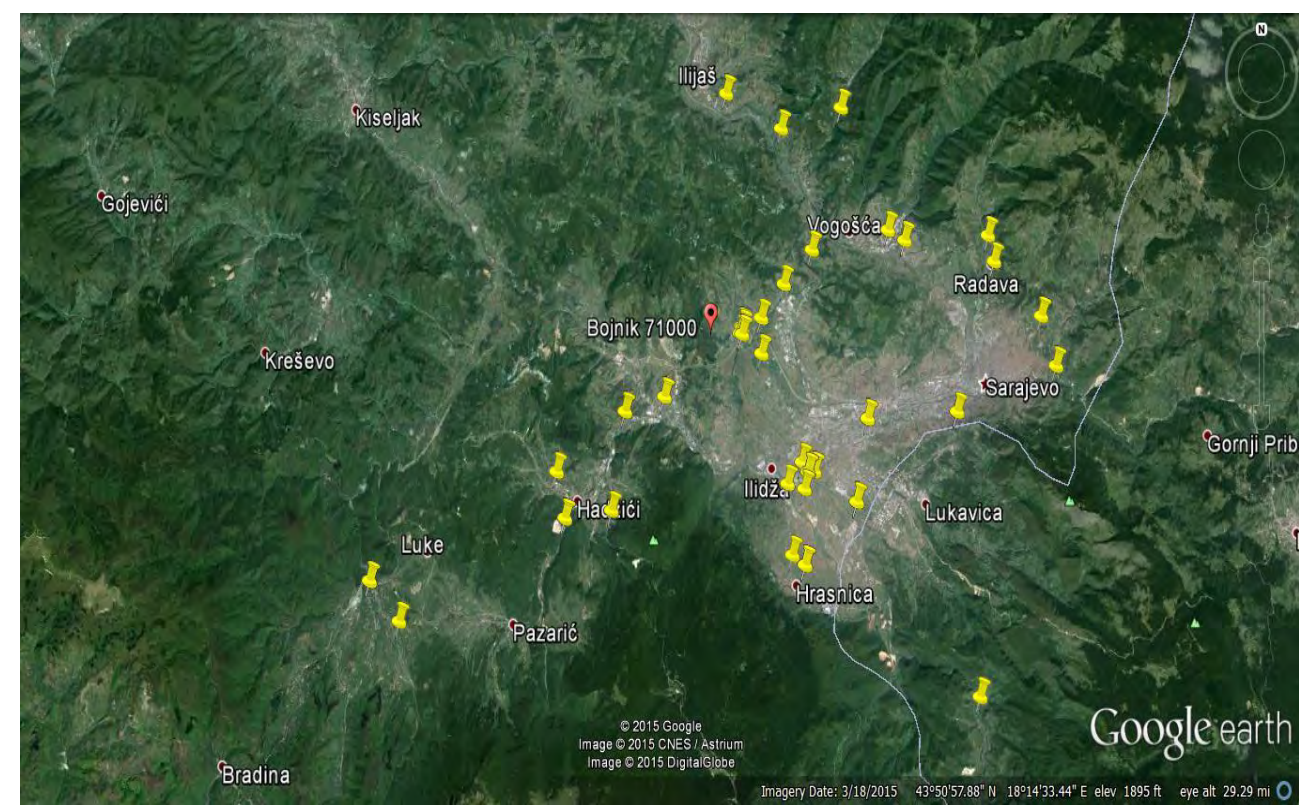

Figure 1. Surveyed area and position of registered Jerusalem artichoke stands

In the municipality Ilijaš Jerusalem artichoke was recorded on the ruderal area. In the municipality Ilidža it was found on 20 locations. In the Butmir settlement it was recorded on the seven locations, mostly along the road from municipality building to the junction Sokolović Kolonija - Hrasnica. On the location near municipality building on the ruderal soil this species takes area around 2,000 $\mathrm{m}^{2}$. Number of plants 
per $1 \mathrm{~m}^{2}$ on this location is 95 , while the plant height in blooming phase was to 200 $\mathrm{cm}$. Žgančikova et al. (2012) found location with 265 plants per $\mathrm{m}^{2}$. On the ruderal area Jerusalem artichoke was recorded in Butmir settlement - bus station near the bridge on the river Tilava. It was recorded on the agricultural soil on the stubble in the area of Federal agricultural institute. Also it was found in the corn on four locations. At the experimental field of Faculty of Agriculture and Food Sciences it was recorded 80 plants per $\mathrm{m}^{2}$ with average height of $1.3 \mathrm{~m}$. This species was also recorded in other parts of this municipality, in the Osjek and Bojnik settlements. However, given that Jerusalem artichoke likes moisture soils it is located along sides of river Bosna and Željeznica with the high density.

In the municipality Hadžići Jerusalem artichoke was found on the sides of river Zujevina. Mostly those are communities with 13 to 35 plants per $\mathrm{m}^{2}$.

From the aspect of invasive weed species municipality Trnovo was mostly examined along regional road Sarajevo - Goražde. Jerusalem artichoke was found in the valley of river Željeznica.

In the Novi Grad municipality Jerusalem artichoke was found on ruderal area and on the sides of river Bosna in Rajlovac settlement.

In the Stari Grad municipality Jerusalem artichoke was recorded on the part of child playground near bridge Kozija ćuprija and in Sedrenik settlement near the road.

Municipality Novo Sarajevo is in the center of the city so only one location of Jerusalem artichoke was found and it is in Vraca settlement, road to Lukavica.

In the Centar municipality Jerusalem artichoke was found on two locations and it is in Nahorevo and Pionirska dolina settlements. The abundance of Jerusalem artichoke is particularly striking in the Pionirska dolina settlement near the Koševski stream. On this abounded and moisture soil it has height over $150 \mathrm{~cm}$ with 55 plants per $\mathrm{m}^{2}$.

In the center of municipality Vogošća, where the areas are orderly maintained, there are no recordings of any locations with this species. Going to the Sarajevo from Vogošća through Hotonj and Kobilja Glava settlements there are some locations of this weed. Near the gas station El-Tarik one big location of Jerusalem artichoke was recorded with 40 plants per $\mathrm{m}^{2}$ and height up to $170 \mathrm{~cm}$. Jerusalem artichoke was also found near river Vogošća which was expected since this weed likes moisture soils especially near waterways. In the Hotonj settlement there was also one location recorded (across gas station Hifa) with 15 plants per $\mathrm{m}^{2}$. Jerusalem artichoke (Helianthus tuberosus (L.)) was found mainly on the riverbanks in dense populations (Žgančikova et al., 2012). On the road to Tuzla several locations of Jerusalem artichoke were found, near the river Ljubina. There was up to 50 plants per $\mathrm{m}^{2}$ with the height up to $140 \mathrm{~cm}$. 
In order to develop effective eradication measures of this invasive weed, it is necessary to conduct more detailed research, especially on the agricultural land that has limited access. In nine municipalities in Canton Sarajevo only in municipality Ilidža it was found on the agricultural areas.

\section{CONCLUSIONS}

- Research conducted during one vegetation season in nine municipalities in Canton Sarajevo confirms the existence of Jerusalem artichoke in all municipalities. In total it was found on 42 locations with the biggest number in Ilidža municipality.

- In all municipalities this weed species was found on ruderal area, while only in municipality Ilidža it was found on stubble and in corn. The highest number of Jerusalem artichoke on rudereal area is also because of the fact that access to this area is undisturbed, while entering private areas was a problem which happened in this research.

- The highest number of plants per $\mathrm{m}^{2}$ was recorded in Ilidža municipality -95 . On the eight locations number of plants per $\mathrm{m}^{2}$ was bigger than 50 , while the biggest number of locations were from $10-50$ plants per $\mathrm{m}^{2}$.

- In order to develop effective eradication measures of this invasive alien, it is necessary to conduct more detailed research as well as on non-agricultural and agricultural areas, but the focus should still remain on removal of vegetative growth.

\section{REFERENCES}

Bećar, A., M. Đikić, D. Gadžo, H. Berberović, T. Gavrić. 2009. Čičoka (Helianthus tuberosus) - korov ili kulturna biljka. Zbornik rezimea VI simpozija o zaštiti bilja, Tuzla. BiH.

Labant-Hoffmann, E. and G. Kazinczi. 2014. Chemical and mechanical methods for suppression of Jerusalem artichoke (Helianthus tuberosus L.). Herbologia, 14 (1), 63-69.

Novak, R., I. Dancza, 1. Szentey, J. Karaman. 2009. Arable weeds of Hungary, Fifth national weed survey, Budapest.

Radovanović, A., S. Cupara, M. Tomović, V. Tamas, G. Ivopol, D. Simion, C. Gaidau, S. Janković. 2013. Komparativna analiza hemijskog sastava Heliantus tuberosus L. sa područja Srbije i Rumunije. Serbian Journal of Experimental and Clinical Research. Vol 14 (1), 9-12.

Schittenhelm, S. 1996. Competition and Control of Volunteer Jerusalem Artichoke in Various Crops. J. Agronomy \& Grop Science, 176, 103-110. 
Seiler, G.J. 2007. The potential of wild sunflower species for industrial uses. Helia, 30 (46), 175-198.

Šilić, Č. and S. Abadžić. 2000. Prilog poznavanju neofitske flore Bosne i Hercegovine. Herbologija, 1 (1), 29-40.

Terzić, S., A. Mikić, J. Atlagić, R. Marinković, V. Mihailović. 2007. Morfološka varijabilnost krtola vrste Helianthus tuberosus. Zbornik radova, Sveska 44, 207-214.

Terzić, S., B. Dedić, J. Atlagić, V. Miklič. 2011. Otpornost topinambura (Helianthus tuberosus L.) prema sivo-mrkoj pegavosti suncokreta u poljskim uslovima. Field Veg. Crop Res. 48, 161-166.

Weber, E. 2003. Invasive plant species of the world. A reference guide to environmental weeds. Wallingford, UK, CAB International.

Žgančikova, I., T. Vereš, V. Čurna. 2012. Monitoring of the Helianthus tuberosus (L.) as an invasive weed of natural ecosystems. Research Journal of Agricultural Science, 44 (2), 127-130. 